\title{
Care for the spiritual dimension provided by caregivers in a nursing home
}

\author{
Cuidado à dimensão espiritual prestado por cuidadores em instituição de longa permanência para idosos \\ Atención a la dimensión espiritual proporcionada por los cuidadores en un hogar para ancianos
}

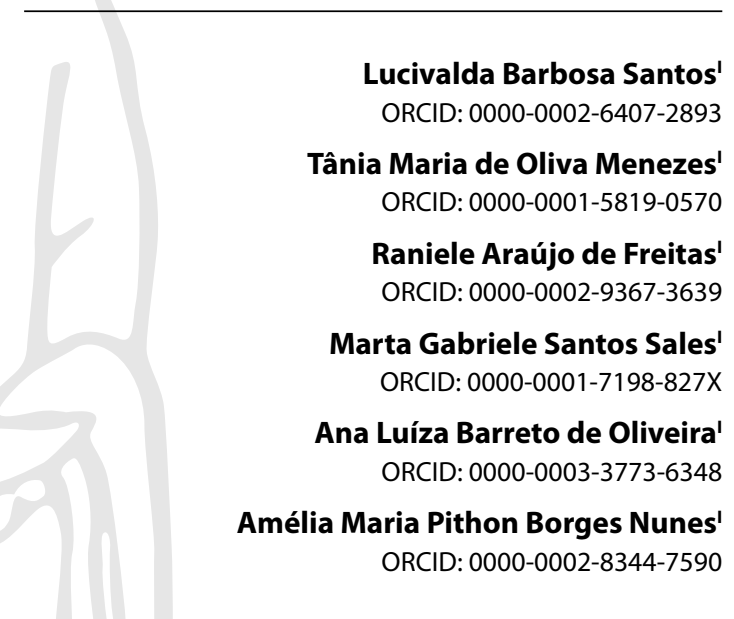

'Universidade Federal da Bahia. Salvador, Bahia, Brazil.

How to cite this article: Santos LB, Menezes TMO, Freitas RA, Sales MGS, Oliveira ALB, Nunes AMPB. Care for the spiritual dimension provided by caregivers in a nursing home.

Rev Bras Enferm. 2022;75(1):e20200402. https://doi.org/10.1590/0034-7167-2020-0402

Corresponding author:

Tânia Maria de Oliva Menezes

E-mail: tomenezes50@gmail.com

EDITOR IN CHIEF: Antonio José de Almeida Filho ASSOCIATE EDITOR: Margarida Vieira

Submission: 07-22-2020 Approval: 04-02-2021

\begin{abstract}
Objectives: to understand care for the spiritual dimension provided by caregivers in a Nursing Home. Methods: this is a qualitative research, carried out in a geriatric center of a philanthropic hospital in the city of Salvador, Bahia. Eighteen formal caregivers participated, through a semi-structured interview, between January and February 2019. The data were analyzed in the light of Jean Watson's Theory of Transpersonal Caring. Results: formal caregivers discuss the spiritual dimension based on older adults' religious beliefs, encourage religious practices and exercise spiritual care according to older adults' physical, emotional and spiritual demands. Final Considerations: formal caregivers understand that older adults' religious or spiritual experiences should be included in their work routine. Care for the spiritual dimension occurs by stimulating faith in God, encouraging religious practices and embracing their beliefs in the face of physical, emotional and spiritual demands.

Descriptors: Caregivers; Homes for the Aged; Aged; Spirituality; Philosophy, Nursing.
\end{abstract}

\section{RESUMO}

Objetivos: apreender o cuidado à dimensão espiritualprestado porcuidadoresem instituição de longa permanência para idosos. Métodos: pesquisa qualitativa, realizada em um centro geriátrico de hospital filantrópico na cidade de Salvador, Bahia. Participaram 18 cuidadores formais, por meio da entrevista semiestruturada, entre janeiro e fevereiro de 2019. Os dados foram analisados à luz da Teoria do CuidadoTranspessoal de Jean Watson. Resultados: o cuidador formal dialoga sobre a dimensão espiritual a partir das crenças religiosas do idoso, incentiva as práticas religiosas e exerce o cuidado espiritual de acordo com as demandas físicas, emocionais e espirituais da pessoa idosa. Considerações Finais: os cuidadores formais compreendem que as vivências religiosas ou espirituais da pessoa idosa devem ser incluídas na sua rotina de trabalho. O cuidado à dimensão espiritual ocorre pelo estímulo a fé em Deus, incentivo às práticas religiosas e acolhimento de suas crenças frente às demandas físicas, emocionais e espirituais.

Descritores: Cuidadores; Instituição de Longa Permanência para Idosos; Idoso; Espiritualidade; Filosofia em Enfermagem.

\section{RESUMEN}

Objetivos: aprehender el cuidado de la dimensión espiritual que brindan los cuidadores en un centro de cuidados de larga duración para personas mayores. Métodos: investigación cualitativa, realizada en un centro geriátrico de un hospital filantrópico de la ciudad de Salvador, Bahía. Dieciocho cuidadores formales participaron, a través de la entrevista semiestructurada, entre enero y febrero de 2019. Los datos fueron analizados a la luz de la Teoría del Cuidado Transpersonal de Jean Watson. Resultados: el cuidador formal dialoga sobre la dimensión espiritual a partir de las creencias religiosas del anciano, incentiva las prácticas religiosas y ejerce el cuidado espiritual de acuerdo con las demandas físicas, emocionales y espirituales del anciano. Consideraciones Finales: los cuidadores formales entienden que las experiencias religiosas o espirituales del anciano deben incluirse en su rutina laboral. El cuidado de la dimensión espiritual ocurre estimulando la fe en Dios, fomentando las prácticas religiosas y abrazando sus creencias frente a las demandas físicas, emocionales y espirituales.

Descriptores: Cuidadores; Hogares para Ancianos; Anciano; Espiritualidad; Filosofía en Enfermería. 


\section{INTRODUCTION}

The population is aging at a great pace in contemporary times. According to the World Health Organization, in developing countries, a person is considered elderly when they are over 60 years old. Brazil has been experiencing a situation characterized by a progressive fall in fertility and a consequent increase in the population's life expectancy, which currently has 28 million people over 60 years of age, representing 13\% of the country's population. The projection is that this number will increase in the coming decades, as the perspective of 2043 is to be a quarter of the population ${ }^{(1)}$.

The increase in life expectancy may be accompanied by chronic non-communicable and disabling diseases in older adults, implying possible physical, cognitive and emotional changes, generating dependency and demands for permanent care for family members ${ }^{(2)}$, who sometimes hire caregivers to assist them in the task of caring.

In this context, the formal caregiver has become a reality in caring for older adults, as they perform some activities that help with their physical and psychosocial limitations. According to the Brazilian Classification of Occupation, the person who is responsible for caring for the sick or dependent person in the following activities is defined as caregiver: food, personal hygiene, education, culture, well-being, leisure and recreation. It is not in the exercise of this profession to perform technical procedures for the nursing team ${ }^{(3)}$.

Basically, the role of caregivers is based on helping older adults in Activities of Daily Living (ADL) and Instrumental Activities of Daily Living (IADL). To be a caregiver, specialized training is required that is capable of providing theoretical and practical knowledge for the role. It also requires emotional, physical and intellectual skills and competences for activities, understanding older adults' limitations and demands ${ }^{(4)}$. For this, it is necessary to participate in courses with a workload of $80 / 160$ hours, be at least 18 years old and complete elementary school ${ }^{(5)}$.

However, formal caregivers still need to expand knowledge about older adults' health, since, in their training, there are gaps for the other realities experienced by older adults. The course has a practice aimed only at basic needs. Caregivers' attention must be multidimensional and must include, in addition to physical, psychological, social and environmental factors, also spiritual needs ${ }^{(6)}$.

During aging, older adults become emotionally vulnerable, due to the diagnosis of the disease, long-term treatment, personal conflicts and withdrawal from family life. Caring from the perspective of religiosity and spirituality is fundamental, as it makes it possible to understand the concerns related to the process of finitude. Many older adults use the spiritual dimension as support, as they believe that their religious belief provides support in times of adversity ${ }^{(6)}$.

The spiritual dimension is important in elder care, in the same way that the biological, psychological and social dimension must be valued, since many older adults, throughout their lives, had a direct proximity to religious and spiritual aspects. This type of care contributes to mitigate or reduce existential conflicts, awakens the hope of better days, with a new meaning and purpose in life ${ }^{(7)}$, despite being little used in practice by caregivers, who emphasize body care.

In relation to the Nursing Home $(\mathrm{NH})$ environment, addressing these issues helps to alleviate anxiety, loneliness, the absence of children and the loss of autonomy. Thus, older adults use spiritual practices as a coping strategy in the face of problems. Believes that trust in God allows us to face the existential conflicts that arise with advancing age ${ }^{(8)}$.

Even without attending, due to their physical limitations, religious places and temples, older adults still maintain the activities of their spiritual beliefs in the very environment that receives care $^{(8)}$. Thus, caregivers must pay attention to valuing and including spiritual needs in care.

In this context, Jean Watson's Theory of Transpersonal Caring (TTC) considers that the spiritual dimension is an enhancing element in the healing process of the being who cares and the being who receives care. Each being is able to transcend the physical, due to their spiritual experience, feelings, emotions and internal forces. Care is implemented when there is involvement and empathy, developed by ten Clinical Caritas Processes: 1. Humanistic and altruistic value system; 2 . Faith and hope; 3. Sensitivity to oneself and others; 4 . Relation of help and trust; 5. Promote and accept positive and negative feelings; 6 . Process of resolute and creative care in solving problems; 7 . Promote transpersonal teaching and learning; 8 . Support and protection environment with a perspective of the physical, mental, social and spiritual dimension; 9. Assistance to basic human needs; 10. Admission of existential, phenomenological and spiritual forces $^{(9-10)}$.

Thus, actions that contemplate spirituality/religiosity can be outlined in the challenge of deepening the process of caring for caregivers from the perspective of the spiritual dimension of older adults who lives in $\mathrm{NH}$. Thus, it was outlined as an investigative question of the study: how do caregivers care for the spiritual dimension of older adults in $\mathrm{NH}$ ?

\section{OBJECTIVES}

To understand care for the spiritual dimension provided by caregivers in a Nursing Home.

\section{METHODS}

\section{Ethical aspects}

The research was approved by the Ethics and Research Committee of the hospital, place of study and conducted according to the standard of research involving human beings, described in Resolution 466/12, 510/16 and 580/17 of the Brazilian National Council of Ethics in Research (Conselho Nacional de Ética em Pesquisa) ${ }^{(11-13)}$.

Participants were identified by letter $C$, followed by an interview order number. The research is linked to the Elder Study and Research Center at the Nursing School of Universidade Federal da Bahia and was approved by the Institutional Review Board of the study site.

\section{Type of study}

This is a qualitative, descriptive and exploratory study, based on Jean Watson's Theory of Transpersonal Caring, guided by the COREQ tool(14). 


\section{Study setting}

The study site was a ward with long-term care, using the housing model, of a geriatric, philanthropic hospital that assists older adults in Salvador, Bahia. In total, there are nine wards, each with a capacity for eight beds, seven female and two male, totaling 72 older adults.

The unit is composed of a multidisciplinary team formed by doctors, nurses, nursing technicians, nutritionists, physiotherapists, social workers and occupational therapists, able to offer assistance for the promotion, treatment and rehabilitation of older adults, with a team of caregivers for older adults, supervised by the unit's nurse. These caregivers perform the function in a 12-hour workday, with an average of 12 professionals during the day and four at night.

\section{Study participants}

Participants were formal caregivers hired by the health institution. Out of a total of 28 professionals, 18 formal contracted caregivers, who have worked as caregivers for at least six months at the institution were included. Participants on vacation, sick leave or maternity leave were excluded. No participant refused to participate in the survey.

\section{Data collection and organization}

The statements were collected between January and February 2019, through semi-structured interviews, in a private environment. The researcher's approach and interaction with the participants were carried out in two stages: the first, aiming at characterizing caregivers' sociodemographic profile; the second, with openended questions to guide data production on the theme. In this contact, it was possible to apply the Informed Consent Form (ICF) and obtain the signature in two copies, authorization to record the interviews and clarify any doubts of the participant.

A digital recorder was used to ensure reports' accurate transcription. The response time was free, and the organization of the data involved transcribing the interviews into Word text files, rereading these materials and structuring the reports. Chart 1 presents the main guiding questions:

Chart 1 -Guiding questions of the interviews, Salvador, Bahia, Brazil, 2019

\begin{tabular}{l}
\hline 1. Does older adults you care for have any religious beliefs? \\
\hline 2. Does older adults you care for have a religious practice or activity? \\
\hline 3. What do you prioritize when caring for older adults? \\
\hline $\begin{array}{l}\text { 4. Do you believe that older adults who has a religious/spiritual prac- } \\
\text { tice interferes with their spiritual care? }\end{array}$ \\
\hline 5. How does religiosity/spirituality influence elder care? \\
Source: data obtainedfromtheresearchproject"O cuidador formal no cuidado a dimensão es- \\
piritual da pessoa idosa internada em Centro Geriátrico: reflexöes a partir da Teoria do Cuidado \\
Transpessoal", Salvador, Bahia, Brazil, 2019.
\end{tabular}

\section{Data analysis}

After the transcription of all statements, content was subjected to thematic content analysis ${ }^{(15)}$, developed by the following steps: pre-analysis, in which an attempt was made to have a comprehensive reading of the selected material and a view of the whole, in order to understand the particularities; material exploration, in which we sought to go beyond the lines and facts, in order to analyze what was hidden and identify thematic units; elaboration of interpretative synthesis, which allowed identifying the central themes, which were grouped into empirical thematic categories. Subsequently, these were analyzed in the light of TTC.

\section{RESULTS}

\section{Characterization of the caregivers participating in the study}

Of the 18 study participants, 13 are female and five are male, highlighting the performance of care for others by women. The average age was 40 years, in an age range that varied between 21 and 51 years. As for marital status, six are married, 11 are single and one is divorced. Regarding religion, ten are Catholics, six are Evangelicals, one is a Spiritualist and one has no religion. The time of profession varied between six months and 21 years at the institution itself. The salary range ranged from one salary, $\mathrm{R} \$$ 998.00 (reais is the Brazilian currency), at the time of collection, to $R \$ 1,200.00$, as the profession is still in the regulatory process, without a defined salary floor.

Among the participants, 17 took a preparatory course, lasting three to four months. As for education, 17 participants have completed high school and are enrolled in higher education.

The exhaustive reading of the speeches, added to the reports on the contexts that surround them, made it possible to elaborate empirical categories. In this way, the categories seized were: Care for the spiritual dimension based on spiritual/religious beliefs; Care for the spiritual dimension by encouraging religious practices; Care for the spiritual dimension based on physical, emotional and spiritual demands.

\section{Care for the spiritual dimension based on spiritual/reli- gious beliefs}

Formal caregivers report that one of the ways to address the spiritual dimension of older adults is to embrace their religious belief through dialogue, listening and attention on the topic:

I believe and do everything to bring my knowledge of God to my elderly, for him to see how good it is. (C4)

Sometimes, an older adult wants to talk about his religion and we are listening and paying attention, showing him that he is paying attention. When older adults speak of God, I also speak, because I believe that I am strengthening, because, older adults who have a religion have something to cling to. This shows him that he is also being taken care of, is helping him. (C9)

There are some elderly women who like to go to mass, then she asks " $C$., I want go to mass!". Then, in the morning, after shower, after breakfast, we will for Mass. (C11)

Because just talking about God to them is a stimulus. I don't let him forget that God exists and that God is our strength, I talk to them about it. (C13) 
Then, they are kind of upset about something, then I say: "don't mind, no. Have faith in God! God is wonderful all the time". (C14)

C9 and C11 discuss the importance and influence that religious beliefs and dialogue about the divine have in the health-disease context. However, one caregiver reported that the demands in the work routine make it impossible to offer care in this perspective, as mentioned below:

Often not, because we soon arrive stifled to give the baths to advance. So, it is a moment that we forget to talk about the love of God, to talk about the belief of one and the other. (C10)

\section{Care for the spiritual dimension by encouraging religious practices}

Participants reveal that care for the spiritual dimension occurs through the encouragement of religious activities, such as prayers, participation in mass, singing and the use of sacred objects, such as the rosary:

She sings candomblémusic and I try to encourage it. Singyour song from the orishas [an Orisha is a spirit or deity that reflects one of the manifestations of God in the Yoruba spiritual or religious system]! Inever try to undo it. leven got to the point of defending. (C2)

They like to say the rosary, they like it when we put it on the radio to listen to Ave Maria. There are some who like some saints. (C5)

She says her prayers alone. In the morning, she prays, because she knows that I will always ask her! (C14)

Arranging and encouraging to go to church to seek the Lord, to be talking, to ask and to thank. (C15)

Participants report the existence of mutual respect and participate in religious activities with older adults, even if they are not from their religion:

We respect each one with their own beliefs. (C1)

lam a person who respects all religions. Mymother taught that everyone has their religion and we have to respect it. I think that older adults being Catholic or evangelical, I will always get something positive from him, and he will always get something positive from me. (C2)

I read the Bible and sang a hymn with them and they felt good. Regardless of my religion or not, I had to act like a professional. (C12)

When we see what kind of religion he is, we try to adapt, right? His kind of religion. We will do our part, but also, respecting his religion. (C14)

So, it is because there are people who are Catholic, evangelical, but God is one! I think so! (C16)

So, I respect older adults, their beliefs. (C17)

Despite the respect shown in the statements, $\mathrm{C} 18$ points out that he finds it difficult to respect individual religious beliefs and practices:
Care for the spiritual dimension provided by caregivers in a nursing home Santos LB, Menezes TMO, Freitas RA, Sales MGS, Oliveira ALB, Nunes AMPB.

For my elderly women, I pray, I sing praise, I play, I speak of Jesus. It is not easy, but people try to speak in a way respecting the opinion of each. (C18)

\section{Care for the spiritual dimension based on physical, emo- tional and spiritual demands}

Participants understand that institutionalized older adults have negative feelings due to physical limitations, family abandonment and living with chronic diseases. Changes in mood are also present, due to hopelessness and discouragement for life:

There was a patient who was sick. When I arrived the other day, I picked it up, prayed and said: "Don't worry, I will pray for you". (C8)

If I see that an older adult is a bit down and that person says, speaks a lot about God, I tell him to believe in God, to stand firm and have faith in God. (C9)

Italk about religion; I talk to have faith in God. That God will not let this happen to them. Many speak when they are sad: "Ah, I want to die! I'd rather die!"I say, "Have faith in God! God is wonderfu!!". (C14)

Older adults, because they are weak and away from relatives, I talk to them. I tell them about their faith, what they trust. And there I work with older adults, putting their faith practice. (C17)

Participants report that they do not find it difficult to include care for the spiritual dimension, because they believe that transcendental strength will benefit both older adults and themselves:

You start saying prayers with him. When we are finished, you feel that he is in a different way, he is more loving, he is more open to you. (C3)

I think it interferes positively, because when you take care of a religious person, they see things differently [...]. (C6)

They help at all times, because they also think about us. They try to help, because they are worried and pass that affection to us. (C7)

\section{DISCUSSION}

In the aging phase, spirituality comes from the ability to withstand mishaps, difficulties and losses intrinsic to this phase, in which there is a diversity of spiritual experience, having in common the recognition of its relevance to aging with quality of life ${ }^{(16)}$. In this sense, it is in this age group that there is a greater involvement of religious practices or activities. Older adults identifies that the spiritual dimension is a form of self-care. The approach to God promotes a feeling of peace and serenity ${ }^{(17)}$, which refers to the need for caregivers to bring spiritual care to their practices.

The meaning of caring takes into account the person's human dignity, subjectivity, choices and emotions. It starts from the moment when caregivers enter the life history and phenomenological field of older adults, going beyond what is provided for in the norms and rules established as the only form of treatment ${ }^{(18)}$.

Formal caregivers, by including care for the spiritual dimension, legitimize other possibilities of care that can benefit older 
adults. Thus, transpersonal care occurs ${ }^{(9)}$. One of the ways of taking care of the spiritual dimension is dialogue with patients, which runs through the words of encouragement to faith, belief, strength and acceptance ${ }^{(19)}$. In the study on screen, participants dialogue with older adults about the spiritual dimension. When addressing and transmitting knowledge about God, caregivers believe that dialogue about their religious beliefs will be good for older adults, so that they do not forget their existence. By placing trust in the superior being, older adults can be calmer to ease the questions about life, the loss of people and the distance from their own family, common in older adults who live in $\mathrm{NHs}$.

TTC has a basic premise that, with the mind and its emotions, the human being is able to connect with their soul. When caregivers offer care in this perspective, they present a personal, moral, social and spiritual involvement, committing themselves to other needs that go beyond the physical order ${ }^{(9)}$.

The first Caritas Process addresses the formation of a system of humanistic-altruistic values, placing caregivers as agents of loving-kindness and equanimity, because taking care of the spiritual dimension of the other is characterized as a set of actions on behalf of the other, when meeting, assisting and respecting their needs, demonstrating practices of love and kindness ${ }^{(9-10,18)}$. In this sense, older adults are fully understood, so the spiritual dimension must be present in caregivers' routine.

TTC argues that the care process is a special moment that should be valued. Thus, when the participants talk about spirituality/religiosity with older adults, there is a harmony of mindbody-soul of both ${ }^{(20)}$ that allows valuation of their existential and spiritual needs.

The second Caritas Process comprises the strengthening of the spiritual dimension of older adults, providing social, physical and emotional well-being through their religious beliefs ${ }^{(9-10,18)}$. For participants, when older adults seek the presence of God, find support, live feelings of hope, become resilient and have the possibility to accept unpleasant facts in a positive way. This reinforces the need for the religious activities of older adults who reside in $\mathrm{NHs}$.

Participants motivate and stimulate older adults' religious beliefs, encouraging participation in the church, prayer, singing, praising and the use of objects of religious representation. By validating older adults' beliefs, caregivers show the importance of this practice to maintain their faith and hope. The inclusion of religious activities is important because it helps older adults to overcome physical limitations, dependence and family losses as well as questions about the finiteness of life. Spirituality is a strategy that can provide better well-being and alleviate stressful events that occur in the aging process ${ }^{(20)}$.

The third Caritas Process ${ }^{(18)}$ establishes that the sensitivity for themselves and for the other is present in participants' practice, evidenced in their attention so that older adults have a transcendental encounter through religious practices, respecting the religiousness/spirituality of older adults and participating with them in these activities. Motivating to pray the rosary and reading the Bible shows a commitment to care that goes beyond the ego itself, enabling spiritual growth and a balance between body, mind and physical ${ }^{(18)}$ of older adults. When patients perceive care based on professionals' closeness and welcoming, there is a feeling of support, comfort and safety ${ }^{(9)}$.
TTC has a basic premise that, by accessing the mind and emotions, the human being is able to connect with his soul. When caregivers offer care in this perspective, they present a personal, moral, social and spiritual involvement, committing themselves to other needs that go beyond the physical order ${ }^{(18)}$.

The Caritas Processes room develops from the relationship, trust and the exchange of experience between both, since caregivers perceive the need to help and collaborate with older adults, when they ask if they have already said the prayer and send it to Mass. A study reports that meeting the spiritual needs of older adults occurs with encouragement to prayer ${ }^{(21)}$. When establishing a relationship of trust and bond at the time of care, caregivers identify that, in addition to biological needs, older adults need spiritual comfort in times of hopelessness, discouragement for life $\mathrm{e}^{(10-11,18)}$.

In TTC, care is not only seen when carrying out and fulfilling tasks or protocols. The theory is applicable precisely at times when invasive interventions and procedures must be replaced by a spiritual approach. It encompasses other dimensions about health and the relationship between the person who cares and the person who receives care, as both emotions and subjectivity are present ${ }^{(22)}$. Transpersonal care leads to changes in objectives, as it involves the mischaracterization of care with practices that are only of a physical, technical and impersonal nature ${ }^{(18)}$.

The fifth Caritas Process proposes the presence and support of caregivers at times when positive or negative feelings are expressed, especially when the spiritual dimension is used as a solution to the problems experienced by older adults, especially at times when older adults express feelings about death. Respecting and valuing this feeling constitutes a welcoming for the spiritual need, whose emotions act as a conductor of care, which is also therapeutic ${ }^{(9-10,18)}$.

In transpersonal care, these sentimental manifestations are a comprehensive part of the human being, and cannot be canceled or devalued. The recognition of the existence of moments of emotional difficulties present in caregivers' routine needs to be improved or confronted ${ }^{(9-10)}$.

The sixth Caritas Process assumes that caregivers need to use their "self" creatively. The intermediary of art, instinct and skills is a strategy to solve problems in caring for older adults, being able to employ a technique or creative method that helps in their decisions using technical and empirical basis ${ }^{(9-10,18)}$. Caregivers used the spiritual dimension as a solution to problems at a time when older adults had physical, emotional and spiritual weakness.

TTC understands the human being in their existential dimension, since he cannot care for the other, disregarding his individuality, subjectivity, mind, body, spirit and soul. For the care to be effective, the other is identified as a complete being, capable of potentialities and internal forces for healing ${ }^{(23)}$. Although caregivers always take care of biological needs as a priority, the spiritual dimension was also part of their practices, even if it occurred in a shorter time, considering the care routine demands. A study points out that caregivers need to adapt to the routine of care provided to older adults, with rules and times defined for daily activities, such as hygiene, food and medication ${ }^{(24)}$.

The seventh Caritas Processes discusses the role of health professionals and the promotion of transpersonal teaching and 
learning. When they are offering transpersonal care, caregivers must take into account that conveying information and knowledge about religious beliefs has the peculiarity of respecting and welcoming the other, entirely, through bonding and empathy ${ }^{(9-10,18)}$.

In practice, it is noted that many professionals do not feel confident in addressing this issue and include it in a care plan, since deficiencies in discussions on the topic during training, the lack of time and distance on the topic are the main justifications presented, even though aware of the benefits for patients ${ }^{(25)}$. Lack of time for spiritual care was also signaled by the participants, as caregivers prioritized care for older adults' biological needs and safety.

The eighth Caritas Process is also identified, as it makes it possible for the environment in which care takes place to become a healthy energy field at the physical, mental and spiritual level, that is, an environment that is a healing for both involved individuals $s^{(9-10,18)}$. When addressing religion, religiosity and spirituality, participants believe in the potential benefits for older adults and also for the place where care is provided. The study's institution has a chapel and has regular Mass times, in addition to having nuns present in activities' routine, which also presents itself as a stimulus to religious practice.

The ninth Caritas Process is evident, since older adults' needs are weakened, and spiritual need is a priority care to meet those needs $s^{(9-10,18)}$. They understand that the existence of God or the Sacred contributes to the being cared for experiencing protection and comfort in all its limitations.

TTC is considered as a therapeutic care practice, as it brings people with human conditions together to care for and care for one another, according to their proximity. There is a need to understand that caring for others must be based on how it happens and not what happens. Centering care on how it creates conditions for growth in the spiritual field of the beings involved ${ }^{(10)}$.

The tenth Caritas Process is present when caregivers identify that the presence of existential and spiritual forces can help older adults, especially when there are mood changes ${ }^{(9-10,18)}$. Thus, at times when there was discontent and discouragement due to issues related to the finitude of life, participants identified that, for the feeling of revolt, discouragement and sadness of older adults, it was necessary to resort to religious and spiritual forces to help them.

As he is more sensitive and vulnerable, older adults use spiritual distress as a resilience strategy to face stressful events, seeking transcendental forces, divine protection and comfort in religion. Spiritual distress understands that people use their spirituality in search of the meaning of life, with positive results in theirroutine ${ }^{(26)}$. Thus, caregivers must be attentive to the manifestations of older adults so that spiritual care is present in their work routine.
TTC argues that the spiritual dimension is included in care ${ }^{(10)}$, and it should not override the valorization of technical and professional actions in care practices. Participants showed that the human being is not just a body, but a potential being with a history of life, psychosocial qualities and characteristics, life expectations that relate to the Sacred and should be valued.

It is relevant to broaden the look before older adults seen not only as a bio-psycho-social being, especially including the spiritual need $^{(27)}$. In this sense, the spiritual dimension presents itself as a dynamic with the potential to promote, with participants, their recovery process ${ }^{(9-10)}$, and should be part of caregivers' assistance in the whole process of caring for older adults who live in $\mathrm{NHs}$.

\section{Study limitations}

The study limitation is related to non-generalization of its results to all caregivers of older adults, since it refers to a group of workers from a specific long-term place. However, the results signal the need to develop planning for caregivers of older adults about spiritual care, in a theme little explored in the context of formal caregivers that can be applied to caregivers who experience situations similar to those of the research participants.

\section{Contributions to nursing and health}

The study results reiterate the importance of caring for the spiritual dimension of older adults who lives in $\mathrm{NHs}$ by caregivers. Understanding the context of aging, added to the institutionalization process, may stimulate reflection on the benefits arising from the spiritual dimension, suggesting that discussions on this theme be promoted in the training and routine of formal caregivers. It also refers nurses to the inclusion of Nursing Care Systematization in caring for the spiritual dimension of older adults and in clinical practice in general.

\section{FINAL CONSIDERATIONS}

The study learned how spiritual care for older adults is provided by caregivers in $\mathrm{NH}$, revealing the spiritual need as a comprehensive part of their care, despite the work dynamics that prioritize biological aspects. Thus, transpersonal care is based on the perspective that caregivers must allow and empower older adults to use spirituality and religiosity to better live in the face of the challenges of aging and institutionalization.

By providing older adults to approach their spiritual needs, caregivers introduce transpersonal care, recognizes the benefits and values the transcendental aspects, aiming to achieve satisfactory results in the care process.

\section{REFERENCES}

1. Instituto Brasileiro de Geografia e Estatística (IBGE). Censo 2020. Idosos indicam caminhos para uma melhor idade[Internet]. Rio de Janeiro: IBGE; 2020 [cited 2020 Jun 12]. Available from: https://censo2020.ibge.gov.br/2012-agencia-de-noticias/noticias/24036-idosos-indicamcaminhos-para-uma-melhor-idade.html

2. Donati L, Beuter M, Schimith MD. Organização do Cuidado ao Idoso Dependente. Texto Contexto Enferm. 2018;17(1):115-25. https://doi. org/10.15448/1677-9509.2018.1.25727 
3. Cunha CV, Berardinelli LMM, Santo FHE. [The perception of caregivers of the elderly in their daily practice context in a long-term institution]. Enferm Atual. 2018;85(23):21-8. https://doi.org/10.31011/1519-339X.2018a18n85.02 Portuguese.

4. Faht G, Sandri JVA. [Elderly caregiver: analyzing the backgrounds and training of students who finished their elderly caregiver course]. Mundo Saúde. 2016;40(1):21-7. https://doi.org/10.15343/0104-7809.201640012127 Portuguese.

5. Brandão SV, Crippa A, Schwanke CHA, Caltado Neto A. [Labor rights of caregivers of the elderly: integrative review]. Rev Kairós. 2017;20(2):229-45. https://doi.org/10.23925/2176-901X.2017v20i2p229-245 Portuguese.

6. Scortegagna HM, Pichler NA, Fáccio LF. The experience of spirituality among institutionalized elderly people. Rev Bras Geriatr Gerontol. 2018;21(3):2401-3. https://doi.org/10.1590/1981-22562018021.180011

7. Oliveira ALB, Menezes TMO. The meaning of religion/religiosity for the elderly. Rev Bras Enferm. 2017;71(2):770-6. https://doi. org/10.1590/0034-7167-2017-0120

8. Santos EL, Navarine TCRR, Costa, MML. [The Elderly and Spirituality: considerations for holistic nursing care]. Nursing [Internet]. 2018 [cited 2020 Jun 10];21(244):2342-44. Available from: http://www.revistanursing.com.br/revistas/244-Setembro2018/O_idoso_espiritualidade.pdf Portuguese.

9. Watson J. Enfermagem: ciência humana e cuidar uma teoria de Enfermagem. Loures: Lusociência; 2002. 182 p.

10. Watson J. Watson's theory of human caring and subjective living experiences: carative factors/caritas processes as a disciplinary guide to the professional nursing practice. Texto Contexto Enferm. 2007;16(1):129-35. https://doi.org/10.1590/S0104-07072007000100016

11. Conselho Nacional de Saúde (BR). Resolução n 466 de 12 de dezembro de 2012. Aprova as diretrizes e normas regulamentadoras de pesquisas envolvendo seres humanos [Internet]. Conselho Nacional de Saúde. Brasília, 2012 [cited 2019 Jan 14]. Available from: http:// conselho.saude.gov.br/ráspolis/2012/Reso466.pdf

12. Conselho Nacional de Saúde (BR). Resolução n. 510, de 7 de abril de 2016. Dispõe sobre as normas aplicáveis a pesquisas em Ciências Humanas e Sociais cujos procedimentos metodológicos envolvam a utilização de dados diretamente obtidos com os participantes ou de informações identificáveis ou que possam acarretar riscos maiores do que os existentes na vida cotidiana [Internet]. Conselho Nacional de Saúde. Brasília; 2016[cited 2019 Mar 31]. Available from: http://bvsms.saude.gov.br/bvs/saudelegis/cns/2016/res0510_07_04_2016.html

13. Conselho Nacional de Saúde (BR). Resolução n 580 de 22 de Março de 2018. Dispõe sobre a regulamentação do disposto no item XIII. 4 da Resolução CNS n 466, de 12 de dezembro de 2012, que estabelece que as especificidades éticas das pesquisas de interesse estratégico para o Sistema Único de Saúde (SUS) [Internet]. Conselho Nacional de Saúde. Brasília, 2018[cited 2019 Apr 01]. Available from: http:// conselho.saude.gov.br/resolucoes/2018/Reso580.pdf

14. Tong A, Sainsbury P, Craig J. Consolidated criteria for reporting qualitative research (COREQ): a 32-item checklist for interviews and focus groups. Int J Qual Health Care. 2007;19(6):349-57. https://doi.org/10.1093/intqhc/mzm042

15. Bardin L. Análise de conteúdo. São Paulo: Edições 70; 2016. 279 p.

16. Molina NPFM, Tavares DMS, Haas VJ, Rodrigues LR. Religiousity, spirituality and quality of life of elderly according to structural equation modeling. Texto Contexto Enferm. 2020;29(e20180468). https://doi.org/10.1590/1980-265x-tce-2018-0468

17. Guerrero FRC, Menezes TMO, Prado ML, Galind AJS. Espiritualidad y religiosidad para la trascendencia del ser anciano. Rev Bras Enferm. 2019;72(Suppl 2):259-65. https://doi.org/10.1590/0034-7167-2018-0840

18. Watson J. Enfermagem pós-moderna e futura: um novo paradigma da enfermagem. Loures: Lusociência; 2002. 299 p.

19. Thauvoye E. Spirituality and well-being in old age: exploring the dimensions of spirituality in relation to late-life functioning. J. Relig Health. 2017;56(5):2167-81. https://doi.org/10.1007/s10943-017-0515-9

20. Veras SMCB, Menezes, TMO. Nurse care for the hospitalized elderly's spiritual dimension. Rev Bras Enferm.2019;72(Suppl2):236-42. https:// doi.org/10.1590/0034-7167-2018-0685

21. Silva MCM, Moreira-Almeida A, Castro EAB. Elderly caring for the elderly: spirituality as tensions relief. Rev Bras Enferm. 2018;71(5):2461-8. https://doi.org/10.1590/0034-7167-2017-0370

22. Matos JC, Guimarães SMF. The application of transpersonal and spiritual care for older adults receiving palliative care. Rev Bras Geriatr Gerontol. 2019;22(5):e190186:1-8. https://doi.org/10.1590/1981-22562019022.190186

23. Watson J. Watson Caring Science Institute: Dr. Jean Watson [Internet]. EUA, 2018 [cited 2018 Feb 04]. Available from: https://www. watsoncaringscience.org

24. Almeida CAPL, Santos LB, Conceição LM, Silva NM, Carvalho HEF, Rocha FCV, et al. A visão de cuidadores no cuidado de idosos dependentes institucionalizados. Estud Interdispl Envelhec[Internet] 2017 [cited 2018 Aug 16];22(1):145-61. Available from: https://seer.ufrgs.br/ RevEnvelhecer/article/view/59844/48383

25. Menezes TMO. Spiritual dimension of care in health and nursing. Rev Baiana Enferm. 2017;31(2):1-3. https://doi.org/10.18471/rbe.v31i1.22522

26. Caires ES, Lander PAA. A religião e espiritualidade no enfrentamento da hospitalização em pacientes idosos. Rev Eletron Teol Ciênc Relig. 2016;4(1):46-155. https://doi.org/10.1590/S0102-37722011000100007

27. Menezes TMO, Freitas AVS, Guerrero-Castañeda RF. Cuidados psicosociales y espirituales de enfermeria a pacientes con demencia que viven en institucion de larga permanencia: algunas reflexiones. Eureka (Asunción)[Internet]. 2019[cited 2020 Apr 27];16(M):201-16. Available from: https://psicoeureka.com.py/sites/default/files/articulos/eureka-16-M-21.pdf 